\title{
Theoretical Framework Over Vivid Facets on Student's Intention To Payback Education Loan in India
}

\author{
Khusboo Srivastava ${ }^{a}$, Dr. Somesh Dhamija \\ ${ }^{\mathrm{a}}$ Assistant Professor, GLA University, Mathura, India. \\ E-mail: khusboo.srivastava@gla.ac.in \\ bProfessor, GLA University, Mathura, India. \\ E-mail: somesh.dhamija@gla.ac.in
}

Article History: Received: 11 January 2021; Accepted: 27 February 2021; Published online: 5 April 2021

\begin{abstract}
Education loan is a magical solution to address the education financing crises. It bridges the gap between accessibility and sustainability but incidents of defaults in the repayment of education loan are on rise. The Present study covers various theories has been thoroughly analysed to understand the factors which influence the intention of student to repay the education loan. A comprehensive theoretical framework has been designed by reviewing various literatures on student intention. This structural framework encompasses - Attitude to repay or default of education loan, Integrity, Parental influence, awareness of loan agreement, Willingness to invest in educational plans, Student's characteristics, Financial ability to pay and student's priority from Theory of reasoned action, Theory of Planned behaviour, Theory of human capital and Theory of ability to pay. In this research study, all efforts have been made to determine the possible linkage between factors that influence student's intention to pay or default the education loan.
\end{abstract}

Keywords: Reserve Bank of India, Attitude and Intention.

\section{Introduction}

Educational loan is the medium via which students having the goal to achieve excellence in academics with the future career at stake of employment so that they can service their debt and also avail the deduction of interest under Income tax Section 80E. As per the Priority sector norms issued by RBI, the maximum limit for education loan available for higher studies in the India is Rs.10 lakhs while studying abroad is Rs.20 lakhs. Financing students to avail collateral free loans upto Rs. 4.00 lakhs comes under the Govt Scheme under Vidya Laskhmi Portal and is available for each and every individual even those who come under LIG and MIG while amount beyond 4 lakhs, student have to provide collateral and a third party guarantee(the parents of the loan applicant student). Education loans are under demand for financing and fuelling the ambition of Young India so that they can pursue their career goals. However, on the flip side the increasing the market share of Education loans of the commercial banks leads to higher delinquency rate as most of the loans are collateral free although Govt provides subsidy to LIG under its scheme of CSISS (Central Sector Interest Subsidy Scheme 2009) through its nodal CANARA Bank whose annual income is not more than Rs. 4.50 lakhs pa. But still the rate of NPA is still on the rising trend. Although the government has launched the CGFEL (Credit guarantee fund for education loans) Scheme to provide incentive to Banks if it comes under the Model Education Loan Scheme of IBA upto Rs. 7.50 lakhs. Taking into the cognizance of student's aspirations for best quality education, Educational loans are gaining popularity to support unaffordable students to study abroad or even at the premier institutions of the country. Students can avail education loans to enrol and pursue the dream of studying higher education from renowned institutions in India and abroad. Collateral free education loan are more prone to risk and there is higher possibility of default. In one side education financing is increasing and on other side it is witnessing the high rate of default in its repayment. Banks concerns towards repayment of study loan have also tremendously increasing. Moreover, banks are currently struggling to manage the high delinquency rate of education loan. In the light of this, there are many driving elements which end up in contributing towards the intention of students to repay the loan. More than 70 countries in the world are encouraging student's education and providing easy and attractive study loans to the students (Shen \& Ziderman, 2009). In India, financing the education is investment for the economic development and future prosperity of the country. Education loan scheme helps to live up the dream of higher education by deserving and academically brilliant students. As per the statistics of Indian Banks Association, 9\% of education loan is declared to be NPA. Default in education loan is worrisome undoubtedly. McWade (1996) delineated that student must consider five facets before opting for education loan. They are earning in future, required time for repayment, rate of interest charged, planning of lifestyle after studies and unanticipated situations that may affect the future earning or repayment ability. This problematic segment deserves more attention and attracts more research opportunity to find out the various reasons behind the delinquency. In similar realm, various factors based on different theories have been identified which influence the intention of student to repay of study loan. Theories based determinants driving students' intention towards loan repayment or towards default have been analysed. 


\section{Conceptual Framework}

To dive deep into the determinants on the student's intention to repay the education loan in India, an extensive theoretical model for the first time has been developed by considering various theories. The concrete model has been built to analyse the impact of various factors on the student's intention towards the study the loan repayment.

The path has been constructed by linking the various constructs from important theories to student's intention of study loan repayment. This research consists of theory of reasoned action (1975), where attitude is considered as attitude is strong predictor of student's intention to repay the debt. The second theory is known as theory of planned behaviour (1991). This modified theory also embrace attitude as integrity for loan repayment attitude, subjective norms are elaborated through parents influence. Next is Human capital theory (1996) which consists of willingness to invest in education credentials and student's characteristics. Last theory is theory of ability to pay where financial capability and student's priority adds towards the intention of the student to repay the study loan.

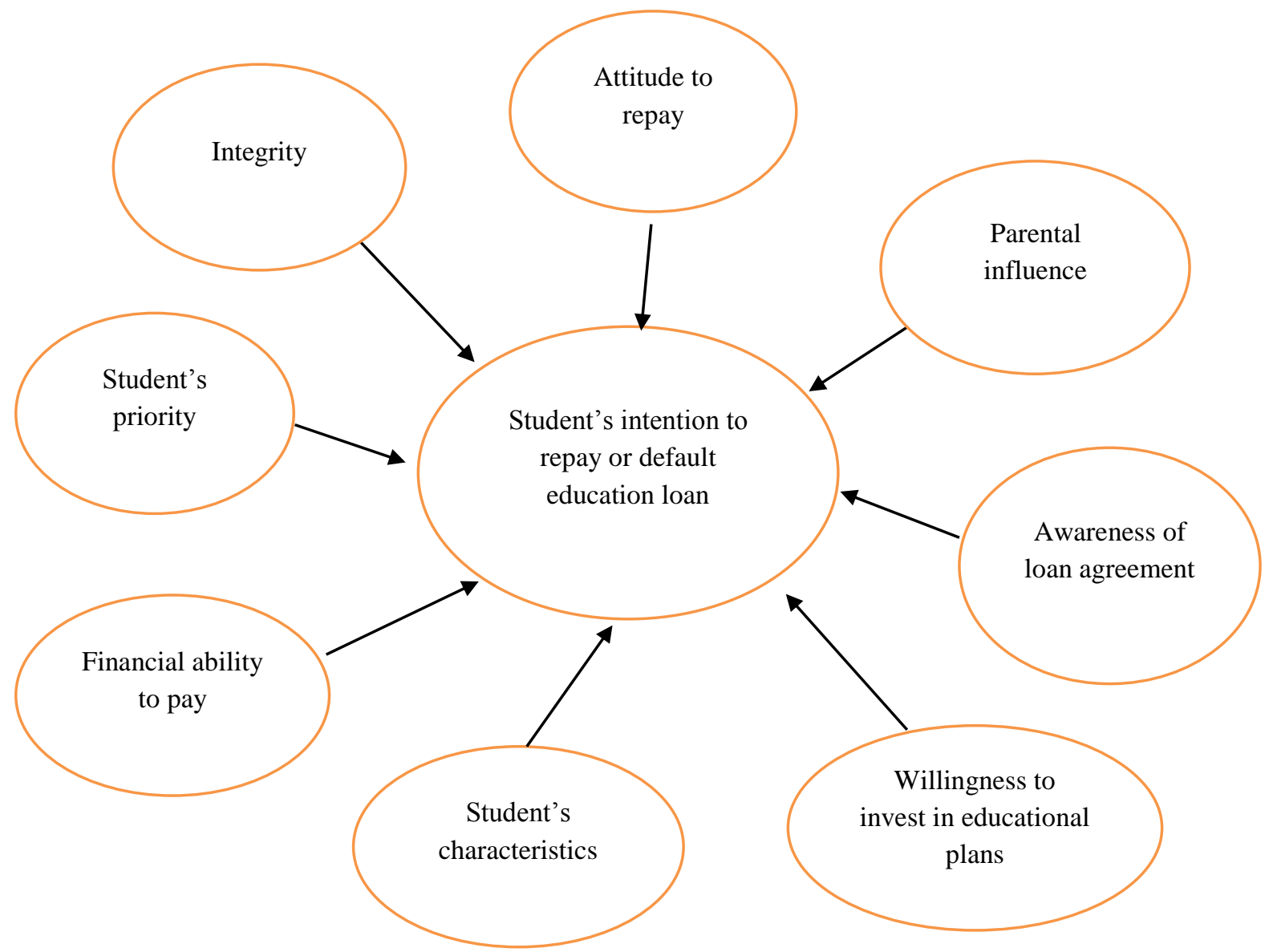

Source: Own creation

Various facets or the factors influencing the student's intention to repay or default education loan has been delineated in following section.

\section{A. Attitude to Repay or Default of Education Loan}

Attitude has its significance to know that why student in spite of having adequate funds for paying of instalments, do not repay their study loan. Attitude towards default is key area for analysis the difference between "willingness to repay" than that of "ability to repay" (Orr, 1987; Volkwein \& Szelest, 1995). McMillion (2004) also affirmed in his empirical study that attitude is one important factor influencing the intention for repayment of loan. Two components indicating repayment and defaults are attitudes and behaviours (Abu Bakar et al., 2006). The Theory of Reasoned Action proffers the association of attitude with behaviour. It is predictive model that suggest how the behaviour of individual is based on pre-existing attitude and behavioural intentions. Ajzen, (1980) developed the model on attitude and attitude behaviour association. The basic element is only behavioural intent. The performance is based on higher the intention to participate in a behaviour. As per the 
theory of Planned Behaviour prompts that the "best predictor of behaviour is intention". To be progressively explicit, intention is basically "cognitive indication of the readiness of an individual to perform a specific behaviour". As intention is function of two basic causal factors: attitude to conduct the behaviour (general assessment of individual to perform the behaviour) and subjective norms (the expectations of others perceived by the individual to perform the behaviour). People generally have strong intentions to perform a given action only if their assessment is positive and if they perceive that others also believe that they ought to perform it. According to some prior studies, education loan is perceived as a burden therefore students have negative perception towards paying the debt. Hence attitude is important element of debt behaviour (Livingstone \& Lunt, 1992). Loan Repayment attitude can be either positive or negative. It is mental and emotional trait of a person. Presence of positive attitude is only when student understands the significance of borrowed money in life and how timely funding transforms his life. Perspective of attitude is elaborated by integrity. Christman (2000) brought additional insights over the attitude by stating that in potential consequences of default, attitude shares the significant relationship with ignorance, dissatisfaction, and misconceptions. TRA model is adopted to examine the determinants that are followed by the borrower to take the decision to the repay debt. The actual attitude of paying back of study loan depends upon how student perceives.

\section{B. Integrity}

Integrity is portrayed as a capacity to show honesty and sincerity and uncompromising adherence to moral principles, ethics and values. (Mondal U., 2013). Students who have finished their examinations ought to have the respectability and trustworthiness to repay their study loans. An examination by Rosli (1998), expressed that borrower's background is significant prior affirming for credit advancement so as to assess certain traits like integrity in the attitude or a practice of being always right. A fair and honest applicant would have integrity which is beyond doubt. The antonym of integrity is selfish attitude to portray the borrowers who don't take care of their responsibility of repaying of the educational loan provided by the banks and other financial institutions. Among the awful perspectives by the students engaged in study loan are: (1) the act of companions that impact the borrower's possibility to default (2) collateral free mindset (3) unscrupulous and flippant (4) Moratorium period. They become bolder to transform into flippant borrowers by following the stride of their companions. The attitude rehearsed by the seniors additionally affected them. Despite of the fact that they have planned for loan repayment and then also they show irresponsible behaviour towards it. The collateral free mentality exist in their mind when borrowed amount limit is upto 4 lakhs, as they know the lender does not possess any assets to fall back in case of default. Instead they should be grateful for moratorium period which is unique feature of education loan. Different banks have different guidelines for it. It is usually 12 months from the completion of studies and 6 month from the starting of the job, whichever comes earlier.

As per various previous researches in other countries (Volkwein \& Szelest, 1995; Baum \& Schwartz, 1988) oppose any linkages between attitudes and behaviour (Ismail et al.2010). Abu Bakar et al. (2006) proclaimed that by and large the students have negative attitude towards debt and its repayment. Henceforth, the negative attitudes and perceptions may influence the repayment of the loan.

\section{Parental Influence}

Human is a social animal and feels pressure exerted by expectations of important people such as family, friends, relatives, peers and neighbours that influence the behaviour of the individual (Nguyen, 2007). If social environment favours the education loan repayment, it likely that student intention not to default will increase. Parents influence is one of subjective norms of theory of planned behaviour therefore plays crucial role on student's intention of paying back the education loan. Contribution of parent is based on family type, race, and their pattern of saving. Planning of financial aid starts at least half year to a year before looking for education loan by student's parents. Guardians need to plan the child's education from portion of their savings, present earning, and future debts. Churaman (1992) revealed guardians assume a definitive role in financing the education and they must consider the management of expanding cost of education is becoming costlier day by day. Therefore borrower qualities will have a measurably significance with a lower likelihood of default are income of the parents, and the nearness of two guardians at home (Knapp and Seaks, 1992). The guardians have importance on the grounds that education loan include family income at the purpose of passage to advanced education (Jackson, 2002; Ziderman, 2004), financial status of student's family (Chung, 2003 \& Ziderman, 2005). The parents do have direct or indirect impact and usually, young people's behaviour is influenced by their parents' approval. Researches in various disciplines recommend that parents can positively affect the advancement of their children's characters and attitude. It has been suggested that contribution of parents is firmly connected with social class. Guardians impact their youngsters straightforwardly, through conversations and upbringing (Ward et al., 1977). Youngsters who converse with their parents normally about positive 
propensities are bound to carry on good behaviour than youngsters whose guardians don't converse with them routinely. Kim et al. (2012) stated that students who lived with their parents or are from affluent families had less student loan debt than the students from lower-income households or families with dependent children.

\section{Awareness of Loan Agreement}

The big question is that do students are having enough knowledge of study loan in regards to their duty in paying their obligation. Students are ignorant of the amount of money they are borrowing, interest rate and other terms conditions (King \& Frishberg, 2001). Volkwein and Cabrera (1998) revealed that perception of student about study loan is that credit default isn't a result of deliberate intention of default and deception. It is additionally found that three out of four students don't know about the options available in regards to payment delay. Besides this, an investigation by Hira et al. (2000) found that regardless of whether student are in a similar course in a similar college, their awareness about the obligation they obtained is different. Thus evaluating the sources empowers one to check their effectiveness in drawing in the awareness on loan agreement (Grolnick and Slowraczek 1994). Student must opt for "loan literacy" for evaluating its debt management. Many students go for higher education after completing their degree and pursue post graduation. Students need to be aware that Banks can give longer moratorium period and fund the higher education also. This will lead to increased financing of the bank for the deserving students and also students will have the option to pursue their career goals and pay the education later on after completing their post graduation degree. Thus it is a win win situation for both as banks get interest rates from the borrowers for longer duration and students get funding to pursue their higher studies. Students are currently turning out to be technology savvy, and relying upon the internet to get quicker information which will build the awareness among the borrower in view of this adequacy in getting the information.

\section{E. Willingness of Individual to Invest in Education Plans}

As education is the driving force for the better earnings and future financial well being. Education is a type of investment which has lifetime returns. The theory of Human capital refers that human tendency is to make investments in the people capital where there are advantages which exceeds the cost of the investment. This theory correlates with even low income group students where they are more academically inclined and willing to pursue higher education. Human capital has the cost which includes the repayment of the principal plus interest of the education loan taken to pursue the education. Even Parents invest their time and money in educating their children. It is said that prospects of getting higher pay grade job can only be through education. Consequently money spent on education presently is a type of investments which prompts more prominent returns in future. Pursuing higher education will help in securing a higher package and hence will improve the chances of securing a higher CTC and thus students will be able to repay the loan faster. The students who are willing to do entrepreneurship would be able to run business and will be able to repay the loan through the business income generated. Thus a study loan facilitates a student to have education even if it unaffordable so act as mode of true earning potential of individual by funding the studies and they are required to repay when employed. Lesser the default rate more funds would be made available to the low income group students (Nyahende, 2013). This Decision making process of education loan is tricky and risky as future is uncertain because the structure of study loan system is based on future assumptions of better job and high earnings.

\section{F. Student's Characteristics}

The Student's characteristics are major source of default according to Chapman (2008) and Wee and Li (2007) suggested that socio-demographics attributes may impact behaviour of an individual. Student debt may risky if student belongs to low socioeconomic group. On contrary Livingstone and Lunt, 1992 indicated that socio-segment factors assumed to have less significance in repayment of debt. Though the behaviour changes over the period of time but some research work suggested that sex, structure of the family, ethnicity, knowledge, and attitude are essential variables identified for behaviour. Earlier investigations conveyed that there is significant correlation between socio demographic characteristics of student and his loan repayment intention. As so to predict the

\section{G. Financial Ability of a Student}


Ability to pay or financial capability of student attributes to his intention to repay the loan. If borrower's income received is not enough to maintain minimum cost of living then repayment becomes secondary and also if a student is unable manage the debt due to the burden of debt along with the cost of living. Some research in US have confirmed that low earnings or income have higher chances of default (Woo, 2002). According to Baum and Schwartz (2005), it is very risky investments as future is uncertain. A student may not be able pass the course or may not get the job, may face some unexpected issues or sudden changes in the earning and its allocation of the borrower and may face some unexpected issues or unavoidable events like medical conditions, recession in economy and unanticipated family conditions. Such unanticipated events may ruin life plan and also student's debt management. Payback decision of student is also based on cost and benefits on relation with default.

\section{H. Student's Priority}

Individual pay off pattern is based on future income and not on the current income. Similarly student borrows the funds from the bank or any financial institution. The repayment starts when graduation or post graduation is completed so that the quality of life after graduation or post graduation is equally important. There are also some students who earn high salary then also don't repay their study loan. There comes the higher priority either on repaying the debt or on the minimum expenditure on their standard of living. Non repayment or default case arises when student prefers other expenses significant. Student's higher priority decision directs repaying the student loan.

\section{Conclusion}

Thus this structured model highlights the key points which attributes to the loan delinquency and default in repayment of education loan. It ascertains the understanding of various determinants of student's intention to repay the loan. It postulates that the stronger a person's attitude, the greater acceptance from family and the greater the financial capability with willingness, the stronger will be intention to repay the student loan. The students who are able to repay the loan and earn a good placement will encourage the other students to avail the loan and support their family. Loan repayments from the borrowers need to be emphasised as it helps in proper credit culture. Poor repayment which results into unavailability of funds to fund the students who are needier and in the low income group. Bottlenecks need to be cleared and instilling proper credit culture in the young borrowers so that the higher CIBIL score is created and good track record of the loan during the tenure is ensured. Otherwise such default may have cascading effect on the Indian economy.

\section{References}

4. Ajzen, I., \& Fishbein, M., (1980a). Attitude_behaviour relations: a theoretical analysis and review of empirical research, Psychological bulletin, 84(5), 888-918.

5. Ajzen, I., \& Fishbein, M. (1980b). Understanding attitudes and predicting social behaviour, Englewood Cliffs, NJ: Prentice-Hall, Inc.

6. Bakar, E.A., Masud, J., \& Jusoh, Z.M. (2006). Knowledge, attitude and perceptions of university students towards educational loans in Malaysia. Journal of family and economic issues, 27(4), 692-701.

7. Baum, S., \& Schwartz, S. (1988). The Impact of Student Loans on Borrowers: Consumption Patterns and Attitudes Toward Repayment, Tufts University, Boston, MA.

8. Baum, S., \& Schwartz, S. (2005). How much debt is too much? Defining benchmarks for manageable student debt, Project on student debt and the College Board.

9. Chapman, B. (2008). Income related student loans: Concepts, International reforms and administrative challenges. In P. Teixeira, D.B. Johnstone, M.J. Rosa., \& H. Vossensteyn (Eds.), Cost-sharing and accessibility in higher education: A Fairer Deal? Dordrecht: Springer.

10. Christman, D.E. (2000). Multiple realities: characteristics of loan defaulters at a two-year public institution, Community college review, 27(4), 16-32.

11. Chung, Y.P. (2003). The student loan scheme in Hong Kong, United Nations educational, Scientific and Cultural Organisation, Bangkok.

12. Grolnick, W.S., \& Slowraczek, M.L. (1994). Parental involvement in children's schooling: A multidimensional conceptualization and motivational model. Child development, 65(1), 237-252.

13. Hira, T.K., Anderson, M.M., \& Petersen, K. (2000). Students' perceptions of their education debt and its impact on life after graduation. Journal of Student Financial Aid, 30(1), 7-19.

14. Ismail, M., Khalid, S.A., Othman, M., Jusoff, K., Abdul Rahman, N., Mohamed Kassim, K., \& Shekh Zain, R. (2010). Entrepreneurial Intention among Malaysian Undergraduates, International Journal of Business and Management, 4(10), 54-60. 
15. Jackson, R. (2002). The national student financial aid scheme of South Africa (NSFAS): How and why it works. The Welsh Journal of Education, 11(1), 82-94.

16. Kim, J., Chatterjee, S., \& Kim, J.E. (2012). Debt burden of young adults in the United States. Journal of Financial Counseling and Planning, 23(2), 55-67.

17. King, T., \& Frishberg, I. (2001). Big Loans, Bigger Problems: A Report on the Sticker Shock of Student Loans. Washington, D.C.: State PRIG Higher Education Project.

18. Knapp, L.G., \& Seaks, T.G. (1992). An analysis of the probability of default on federally guaranteed student loans, The review of economics and statistics, 74(3), 404-411.

19. Li, W. (2007). Family background, financial constraints and higher education attendance in China, Economics of Education Review, 26(6), 724-734.

20. Livingstone, S.M., \& Lunt, P.K. (1992). Predicting personal debt and debt repayment: psychological, social and economic antecedents, Journal of economic psychology, 13(1), 111-134.

21. McMillion, R. (2004). Student Loan Default Literature Review. TG (Texas Guaranteed Student Loan Corporation).

22. McWade, P. (1996). Financing graduate school: how to get money you need for your graduate school education, Newark, New Jersey: Peterson's.

23. Mondal, U. (2013). Integrity, competency and ethical behaviour. International Journal of Marketing and Technology, 3(4), 188.

24. Nguyen, C.H. (2007). Access to credit and borrowing character of rural households in a transition, paper presented at International Conference on Rural Finance Research Moving Results into Policies and Practices, 19-21 March, Rome.

25. Nyahende, V.R. (2013). The Influence of Students' Loans Borrowers' Characteristics on Default Rate in Tanzania. The Journal of Higher Education studies, 3(4), 47-61. http://dx.doi.org/10.5539/hes.v3n4p26

26. Orr, T. (1987). The dilemmas of loan counseling: a practitioner viewpoint: perspective in:Cronin, J., \& Simmons, S. (Eds.), student loans: risks and realities, 50-54.

27. Rosli, M. (1998). Banking and Lending. Kuala Lumpur: Utusan Publications \& Distributors Sdn. Bhd.

28. Shen, H., \& Ziderman, A. (2009), Student loans repayment and recovery: international comparisons, Higher education, 57(3), 315-333.

29. Volkwein, J.F., \& Cabrera, A.F. (1998). Who defaults on student loans? The effects of race, class, and gender on borrower behavior. In R. Fossey \& M. Bateman (Eds.), Condemning students to debt: College loans and public policy, New York \& London: Columbia University, 105-125.

30. Volkwein, J.F. \& Szelest, B.P. (1995). Individual and campus characteristics associated with student loan default, Research in Higher Education, 36(1), 41-72.

31. Wackman, D.B., Ward, S., \& Wartella, E. (1977). How Children Learn to Buy: The Development of Consumer Information Processing, Wilms,

32. Woo, J.H. (2002). Factors affecting the probability of default: Student loans in California. Journal of Student Financial Aid, 32(2), 1.

33. Ziderman, A. (2004). Policy options for student loans schemes: Lessons from five Asian case studies, Bangkok: UNESCO Bangkok, 1(6).

34. Ziderman, A. (2005). Increasing accessibility to higher education: a role for student Loans?. Independent Institute of Social Policy, Moscow. 